\title{
Domestic Election Monitoring and Advocacy: An Emerging Research Agenda
}

Max Grömping, max.groemping@sydney.edu.au

Department of Government and International Relations, University of Sydney, Sydney, Australia

\section{Author manuscript}

The Version of Record of this manuscript has been published, and is available in the Nordic Journal of Human Rights, 35(4), 407-423. https://www.tandfonline.com/doi/full/10.1080/18918131.2017.1401776

\begin{abstract}
:
Holding elections has become a global norm, even in autocracies; at the same time, there is mounting evidence to suggest that flawed or failed elections pose serious risks for political stability, legitimacy, and participation. Scholars and practitioners alike increasingly see domestic election monitoring groups to be a partial remedy to electoral malpractice. At least half of elections globally are monitored by such groups and large sums of international aid spent on them. However, scholarly research about the causes, dynamics, and consequences of domestic election monitoring and advocacy is scattered. This article sets out to present an overview of the academic literature on domestic monitoring. It discusses activities and actors, and presents empirical insights on the prevalence, accuracy, credibility and impartiality of monitors, as well as participation in monitoring, and its impacts on electoral integrity. It outlines gaps and open questions for a future research agenda. The review contributes to the practice, empirics and theory of election monitoring and links to broader scholarly inquiries about the embedding of human rights norms in national elections.
\end{abstract}

\section{Keywords:}

Domestic Election Monitoring; NGOs; Democracy Assistance; Democratisation; Electoral Reform; Advocacy; Electoral Integrity

\section{Introduction}

'In the democracy promotion community we are increasingly aware that the future is domestic observation - it has to be, and everybody knows that.' 1 This is how David Carroll, veteran election observer from The Carter Center, recently summarised the widely held positive expectations among electoral assistance professionals about domestic (as opposed to international) election observation and monitoring. Indeed, supporting civil society groups in recipient countries in the safeguarding of elections is part of a major growth area of international aid. Overall amounts of aid spent on democracy- related interventions - elections, human rights, civil society, and media - tripled in the years from 2002 to 2012, from about US\$ 1 billion per year to about US\$ 3 billion; ${ }^{2}$

\footnotetext{
${ }^{1}$ David Carroll, as quoted in Eric Bjornlund and others, 'Lessons from the Ground: What Have We Learned? What Do We Do next? Roundtable Discussion’ in Pippa Norris, Richard W Frank Frank and Ferran Martinez i Coma (eds), Advancing Electoral Integrity (Oxford University Press 2014) 275.

2 Anna Lührmann, Kelly McMann and Carolien van Ham, 'The Effectiveness of Democracy Aid to Different Regime Types and Democracy Sectors’ (2016) 40 V-Dem Working Paper Series.
} 
and aid more specifically targeted at 'Democratic Participation and Civil Society' amounted to US\$ 2.7 billion from 2001 to $2010 .^{3}$ A wide range of international governmental and nongovernmental organisations work with domestic election monitors through capacity building and/or grant making, and a number of handbooks and guidelines describe the activities, actors, and goals involved. ${ }^{44}$ These publications unanimously praise the virtues of citizen election monitors. The 'A-Z Guide' to domestic monitoring, for instance, a foundational document published by one of the primary funding agencies, the US-based National Democratic Institute (NDI), asserts that domestic monitors contribute to

... more genuine election processes by encouraging fairer campaign practices and a more informed electorate, as well as by reducing the possibility of fraud and irregularities on election day. [They] develop and strengthen institutions essential to the sustainability of a democratic political system, [and] help citizens learn organizational skills necessary to participate actively and effectively in the political life of a country between elections. ${ }^{55}$

Clearly, hopes are high. Not only are domestic monitors expected to deter electoral malpractices, they are also meant to improve institutional and legal frameworks, and build civic skills and social capital. But what do we know through systematic and comparative research about the impact of domestic election monitoring on electoral integrity? ${ }^{6}$ Or about even more basic questions: What type of actors engage in it? Where and why do these actors emerge? How do they hope to strengthen electoral integrity?

In order to answer some of these questions, this article sets out to present an overview of the academic literature on domestic election monitoring and advocacy. It draws on a review of secondary scholarly sources in monographs, edited books, and journal articles. Due to the nascent state of the field, both peer-reviewed and non-peer-reviewed publications are included. Although there are many overlaps with the research agenda on international election monitors, this review covers exclusively studies of domestic election monitoring initiatives, i.e. civil society groups that scrutinise elections in their own countries. Much more is already known about international monitors, ${ }^{7}$ and furthermore, the actors, dynamics, and outcomes of domestic monitoring may be structurally different. Domestic groups are in it for the long haul and have a stake in their own society. While a

${ }^{3}$ Based on the AidData database <http://aiddata.org/> accessed 18 November 2017.

${ }^{4}$ See e.g. National Democratic Institute for International Affairs (NDI), How Domestic Organizations Monitor Elections: An A to Z Guide (NDI 1995); OSCE Office for Democratic Institutions and Human Rights (ODIHR), Handbook for Domestic Election Observers (ODIHR 2003); Paul O’Grady, Rafael Lopez-Pintor and Mark Stevens, The Work of Domestic Election Observer Groups Around the World (Electoral Reform International Services (ERIS)/European Commission 2004); NDI, Monitoring and Mitigating Electoral Violence Through Non-Partisan Citizen Election Observation (NDI 2014).

${ }^{5}$ NDI, How Domestic Organizations Monitor Elections (n 4) vii.

${ }^{6}$ In the context of this article, 'electoral integrity' refers to elections that adhere to 'international conventions and global norms, applying universally to all countries worldwide throughout the electoral cycle, including during the preelectoral period, the campaign, on polling day, and its aftermath. Conversely, the notion of 'electoral malpractice' is used to refer to [...] violations of these global norms': see Pippa Norris, 'The New Research Agenda Studying Electoral Integrity’ (2013) 32(4) Electoral Studies 563, 564.

${ }^{7}$ For a concise review of that literature see Judith G Kelley, 'International Influences on Elections in New Multiparty States’ (2012) 15(1) Annual Review of Political Science 203. Since the publication of that review, other important works have been published, e.g. Ursula E Daxecker, 'The Cost of Exposing Cheating International Election Monitoring, Fraud, and Post-Election Violence in Africa' (2012) 49(4) Journal of Peace Research 503; Alberto Simpser and Daniela Donno, 'Can International Election Monitoring Harm Governance?' (2012) 74(2) The Journal of Politics 501; Daniela Donno, Defending Democratic Norms: International Actors and the Politics of Electoral Misconduct (Oxford University Press 2013); Susan D Hyde and Nikolay Marinov, 'Information and Self-Enforcing Democracy: The Role of International Election Observation’ (2014) 68(2) International Organization 329. 
much-emphasised aspect of international monitoring is the 'certification' of elections in terms of their adherence to international standards, domestic monitors keep up a more sustained engagement over a longer period of time. A closer look at this emerging body of research is therefore warranted.

This review aims to bring together research stemming from different disciplines, such as political science, sociology, economics, area studies, law, and information science, covering the thematic area of domestic election monitoring from different angles. It may prove useful for scholars studying electoral integrity and reform, or public interest groups and domestic influences on democratisation more broadly. It may also be of interest for electoral assistance practitioners by summarising the state of the art of the scholarly debate. In total, 60 studies are included in this review. These are listed in the supplementary materials. ${ }^{8}$

The article proceeds as follows. The next section details the range of activities and actors covered by the literature on domestic monitors. It discusses and tries to synthesise the different definitions found in the surveyed studies. Section 3 summarises the main empirical findings, structured around several prominent themes, namely the prevalence of domestic monitoring initiatives, participation in them, their accuracy in detecting electoral malpractice, their impartiality, their credibility, and finally their impacts on electoral integrity. Section 4 concludes by highlighting open questions and gaps in the literature, and provides some suggestions for fruitful future research.

\section{Defining Domestic Election Monitors: Roles and Actors}

How can one analytically delineate the activity of domestic election monitoring and the actors engaging in it? Much public attention focuses on non-governmental organisations (NGOs) witnessing and exposing election-day irregularities such as ballot box stuffing, multiple voting, or vote count falsification. But not all domestic monitoring groups are NGOs. Further, problems of electoral integrity may emerge at any step of what has become known as the 'electoral cycle'9 - be it related to the electoral laws, the drawing of voting district boundaries, the registration of parties or voters, campaign finance regulation and media reporting, the vote count, or electoral dispute resolution. Electoral malpractice can occur due to deliberate manipulation or due to negligence of lack of resources. The reviewed studies reflect this 'electoral cycle approach', through the range of activities that they subsume under the umbrella of either 'election monitoring' or 'election observation'. Though sometimes used synonymously in the surveyed studies, it should be pointed out that the majority of studies recognise that 'monitoring' includes activities beyond the mere observing of polling places, for instance the presentation of recommendations to improve electoral conduct, the promotion of electoral integrity practices, and possibly the deterrence of misconduct. At the same time, it does not include activities associated with the 'supervision' of elections - tasks more related to electoral administration, which international organisations sometimes took on in the early days of election support. ${ }^{10}$

${ }^{8}$ Supplementary materials to this paper available online at <http://maxgromping.com/njhr-2017-35-4-supplementarymaterials>

9 European Commission, Methodological Guide on Electoral Assistance (European Commission/EuropeAid Cooperation Office

2006).

${ }^{10}$ See Eric Bjornlund, Beyond Free and Fair: Monitoring Elections and Building Democracy (Woodrow Wilson Center Press 2004) 41. 


\subsection{Roles and activities}

A number of studies make recourse to the more widespread and developed practice of international election observation, and treat domestic monitoring as a sub-category. Bjornlund describes (international) election observation as the

... gathering of information about an electoral process and public assessment of that process against universal standards for democratic elections [...] for the purpose of building public and international confidence about the election's integrity or documenting and exposing the ways in which the process falls short. ${ }^{11}$

In their early account of the topic, Nevitte and Canton portray domestic civil society as merely aiding such an international monitoring effort by providing 'the organisational infrastructure and logistical support for the observation; [they] recruit and train observers; and gather, communicate, and analyse the qualitative and quantitative data essential to the systematic evaluation of [...] elections'. ${ }^{2}$ For Lean, on the other hand, monitoring does not simply include the gathering and dissemination of information about the conduct of elections. She rather includes activities such as voter education or lobbying for electoral reform in her slightly more activist view of domestic monitoring. Furthermore, she stresses the aspects of volunteerism and participation in the monitoring activity itself. ${ }^{13}$ The training of volunteers - in some cases up to 500,000 in a single election ${ }^{14}$ - the fostering of deliberation and electoral knowledge among these poll-watchers, are seen as core activities of domestic monitoring in this view.

Birch and van Ham consider domestic election monitors as potential agents for 'societal accountability' and compare their activities with those of the news media, who may play a similar but distinct role. For them, domestic monitors

... seek to promote election integrity [and] work in concert with the media to monitor electoral processes and publicise allegations of abuse [... They signal] areas that need electoral reform and promoting such reform [via] informal channels of communication with EMBs [...] lobbying politicians [...] organising citizen protests to promote (and if needed, demand) reform, as well as seeking change through formal institutions of electoral justice. ${ }^{15}$

This definition clearly extends beyond observation and reporting of irregularities around the electoral cycle, and shifts the focus on electoral advocacy as a key activity. In a very similar vein, Grömping includes in the definition of domestic election monitoring the witnessing of and reporting on electoral malpractices around the whole electoral cycle, and advocacy for the improvement of legal frameworks and procedures. ${ }^{16}$

These definitions echo the 'Declaration of Global Principles for Non-Partisan Election Observation and Monitoring', a document initiated by the Global Network of Domestic Election Monitors (GNDEM) - the most important professional association of domestic

\footnotetext{
11 ibid 40 .

${ }^{12}$ Neil Nevitte and Santiago A Canton, ‘The Role of Domestic Observers’ (1997) 8(3) Journal of Democracy 45, 48.

${ }^{13}$ Sharon F Lean, Civil Society and Electoral Accountability in Latin America (Palgrave Macmillan 2013$) 7$.

14 Seiichi Igarashi, 'The Dilemma of Democratic Consolidation in the Philippines: The Contested Role of Civic Organizations in Electoral Governance’ (2008) 29(52) Philippine Political Science Journal 79, 90.

15 Sarah Birch and Carolien Van Ham, 'Getting Away With Foul Play? The Importance of Formal and Informal Oversight Institutions for Electoral Integrity’ (2017) 56(3) European Journal of Political Research 487, 489.

${ }^{16}$ Max Grömping, 'Domestic Monitors' in Pippa Norris and Alessandro Nai (eds), Election Watchdogs: Transparency, Accountability, and Integrity (Oxford University Press 2017).
} 
monitoring groups worldwide - and endorsed by a large number of intergovernmental and nongovernmental organisations. The document lists in detail 26 elements of the electoral cycle that should - if feasible - be monitored. It stresses mobilisation, observation, analysis, recommendations and advocacy as core components of the monitoring effort. ${ }^{17}$ In sum, existing scholarly works consider a number of activities and roles as integral to domestic election monitoring. The left column of Table 1 summarises these. According to this synthesised definition, the activity of Domestic Election Monitoring consists of witnessing and documenting electoral malpractice around the whole electoral cycle, training volunteers for that purpose, analysing observations and assessing them vis-à-vis international standards of electoral integrity, formulating recommendations to stakeholders, and/or advocating for legislative or procedural changes in the way elections are conducted.

Of course, not every study includes all these activities in its respective definition, but the ones listed in Table 1 are each mentioned by at least five of the studies surveyed. Further to Table 1, it is also worth pointing out some roles and activities excluded by this definition, such as get-outthe-vote campaigns, voting advice applications (VAA), and the monitoring of parliamentarians between elections. Such efforts may strengthen the accountability function of elections, yet they are not aimed at improving electoral integrity as such.

\subsection{Actors}

Who monitors? This question is among the first to be addressed in NDI's aforementioned 'A to Z Guide'. ${ }^{18}$ The publication identifies nonpartisan civic organisations as the core actors. While electoral authorities, political parties, or local media may also place scrutiny on the electoral process, they remain under suspicion of partisanship or having conflicts of interest. Nonpartisan civic organisations are seen to be '... more interested in the process than the outcome of an election'19, evaluating elections through the lens of integrity rather than the policy issues involved or who wins.

Scholarly studies largely agree with this characterisation of the relevant actors. Nevitte and Canton find domestic monitoring to be '... typically mounted by civic organizations or networks of domestic nongovernmental organizations (NGOs)' ${ }^{20}$ while Bjornlund points to '... organizations from civil society rather than the formal political sector, electoral authorities, or political parties'. ${ }^{21}$ In concurrence, Lean speaks of ' $\ldots$ civic associations or networks of associations that advocate for free and fair elections in their home countries'. ${ }^{22}$ These definitions clearly place emphasis on the non-state, non-partisan, and non-media nature of domestic election monitoring.

It is useful to put the discussed studies in relation to several literatures dealing with groups exerting political pressure and trying to influence policy, more broadly speaking

\footnotetext{
17 See GNDEM, 'Declaration of Principles for International Election Observation and a Code of Conduct for International Election Observers' (commemorated at the United Nations, New York, 27 October 2005) <www.gndem.org/declaration-of- global-principles> accessed 18 November 2017.

${ }^{18}$ NDI, How Domestic Organizations Monitor Elections (n 4).

19 ibid 4.

${ }^{20}$ Nevitte and Canton (n 12).

${ }^{21}$ Bjornlund (n 10) 40.

${ }^{22}$ Lean (n 13) 7.
} 
Table 1. The roles and actors of domestic election monitoring.

\begin{tabular}{|c|c|}
\hline Roles/activities & Actors \\
\hline $\begin{array}{l}\text { Witnessing and documenting electoral malpractice } \\
\text { around the whole electoral cycle Non-state, non- } \\
\text { profit, non-partisan, non-media collective actors }\end{array}$ & $\begin{array}{l}\text { Witnessing and documenting electoral } \\
\text { malpractice around the whole } \\
\text { electoral cycle Non-state, non- } \\
\text { profit, non-partisan, non-media } \\
\text { collective actors }\end{array}$ \\
\hline Training of volunteers & Social movement organisations (SMOs) \\
\hline Analysis of observations & $\begin{array}{l}\text { Non-governmental } \\
\text { (NGOs) }\end{array}$ \\
\hline $\begin{array}{l}\text { Assessing elections according to international } \\
\text { standards of electoral integrity }\end{array}$ & Public interest groups \\
\hline Formulating recommendations to stakeholders & $\begin{array}{l}\text { Varying degrees } \\
\text { participation }\end{array}$ \\
\hline
\end{tabular}

(see the right-hand column in Table 1). First, some studies would classify domestic election monitoring initiatives as a sub-type of social movement organisations (SMOs). They may be more or less institutionalised actors within a larger and sustained campaign, consisting of many SMOs and drawing in people who are not connected through formalised relationships but merely sharing a goal - such as electoral reform. The Malaysian group Bersih is an example of such an SMO, embedded within a larger movement. ${ }^{23}$ Similarly, the Russian NGO GOLOS or the Filipino group National Citizen's Movement for Free Elections (NAMFREL) are described as parts of larger movements. ${ }^{24}$ What delimits election monitors from other types of electionfocused SMOs is their political non-affiliation with any particular party or candidate. To be sure, 'non-affiliated' in this context does not mean that the group in question has no partisan bias. This is indeed a matter of empirical examination. But it means that political parties and their appointed scrutineers are not domestic election monitors according to this definition.

Second, domestic election monitoring initiatives are also akin to interest groups. Just like these, they are associations of organisations or individuals who try to influence public policy in their interest by engaging legislators and policymakers in a variety of ways. They might lobby parliamentarians to enact new electoral legislation, or talk directly to the electoral authorities to influence them in their administration of ordinances or procurement of equipment. An example is provided by Vowles' study of the Electoral Reform Coalition (ERC) in New Zealand, found to be instrumental in the success of the 1993 change from a majoritarian electoral system to a mixed member proportional (MMP) system. ${ }^{25}$ Another investigation of the functioning of domestic monitors as interests groups is the study by Celis and collaborators. ${ }^{26}$ The important question in distinguishing domestic monitors from other election-related interest groups is whether the group '... seeks a collective good, the achievement of which will not selectively and materially benefit the membership or activists of the organization', ${ }^{27}$ or whether it conducts its advocacy for private

${ }^{23}$ Ying Hooi Khoo, 'Malaysia’s 13th General Elections and the Rise of Electoral Reform Movement: Rise of Malaysia’s Electoral Reform Movement’ (2016) 8(3) Asian Politics \& Policy 418.

${ }^{24}$ See Andrey Semenov, Olesya Lobanova and Margarita Zavadskaya, 'When Do Political Parties Join Protests? A Comparative Analysis Of Party Involvement In "For Fair Elections Movement” (2016) 32(1) East European Politics 81; Eva-Lotta E Hedman, ‘Mapping the Movement: NAMFREL in Six Philippine Cities’ (1999) 7(2) South East Asia Research 189, respectively.

25 Jack Vowles, 'The Politics of Electoral Reform in New Zealand' (1995) 16(1) International Political Science Review 95.

${ }^{26}$ Karen Celis, Mona Lena Krook and Petra Meier, 'The Rise of Gender Quota Laws: Expanding the Spectrum of Determinants for Electoral Reform’ (2011) 34(3) West European Politics 514.

${ }^{27}$ Jeffrey M Berry, Lobbying for the People: The Political Behavior of Public Interest Groups (Princeton University Press 1977) 9. 
gain. Interest groups lobbying on behalf of companies for the procurement of their electronic voting machines, for instance, are excluded from the definition - even if that procurement might have the effect of improving electoral integrity.

Third, a large number of studies discuss domestic monitors in the terminology familiar to studies of non-governmental organisations (NGOs): voluntary not-for-profit groups, unaffiliated with government, who provide services or perform advocacy. In addition to their advocacy function already described above, the service they might perform is their observational activity, the provision of evidence-based information about the conduct of elections. Two important delimitations distinguish domestic monitors from other NGOs working on electoral integrity: on the one hand, international election monitoring NGOs such as The Carter Center are excluded by definition. On the other hand, domestic NGOs created or controlled by governments (so-called GONGOs) are usually not considered domestic election monitors. ${ }^{28}$

Finally, some of the reviewed studies broaden the definition to include 'crowd' participation in domestic election monitoring. Organisational morphologies have profoundly changed due to networked information communication technologies (ICTs). Microblogging, online social networking sites, crowdmapping, live-streamed videos, and their embedding in mobile phone apps afford '.. asynchronous coordinated actions without the necessity of physical or temporal copresence'. ${ }^{29}$ These new technologies allow the mobilisation of volunteer election observers at a fraction of the cost; they allow training, internal communications, and coordination between large 'crowds' of movement and core staff without scale-up costs; and they afford the collection of eyewitness reports from a theoretically unlimited number of local observers in remote polling locations. This digitally enabled form of election scrutineering is interchangeably labelled 'popular', 30 'social' ${ }^{31}$ or 'crowdsourced' ${ }^{32}$ election monitoring. Examples are provided by studies of crowdmapping initiatives in Nigeria, ${ }^{33}$ Russia, ${ }^{34}$ or Turkey, ${ }^{35}$ where the general public is asked to submit observations about electoral malpractice via SMS, web form, Twitter or other means, which are then collated on a public online map (sometimes after verification by trained observers). Other studies consider crowdsourced quick counts which ask online users to verify official vote tallies based on photographs. ${ }^{36}$

28 Patrick Merloe, 'Election Monitoring vs Disinformation' (2015) 26(3) Journal of Democracy 79. However, for a different view see William A Callahan, Pollwatching, Elections and Civil Society in Southeast Asia (Ashgate 1999).

${ }^{29}$ Steven Livingston, 'Digital Affordances and Human Rights Advocacy’ (2016) 69 SFB-Governance Working Paper Series.

30 Archon Fung, 'Popular Election Monitoring: How Technology Can Enable Citizen Participation in Election Administration' in Guy-Uriel E Charles, Heather K Gerken and Michael S Kang (eds), Race, Reform, and Regulation of the Electoral Process: Recurring Puzzles in American Democracy (Cambridge University Press 2011).

31 Thomas N Smyth and others, Lessons in Social Election Monitoring (ACM 2016).

${ }^{32}$ Max Grömping, 'Many Eyes Of Any Kind? Comparing Traditional and Crowdsourced Election Monitoring and Their Contribution to Democracy' (2nd International Conference on International Relations and Development [ICIRD 2012], 26-27 July 2012); Catie Snow Bailard and Steven Livingston, 'Crowdsourcing Accountability in a Nigerian Election’ (2014) 11(4) Journal of Information Technology \& Politics 349.

33 Bailard and Livingston (n 32).

${ }^{34}$ Max Bader, 'Crowdsourcing Election Monitoring in the 2011-2012 Russian Elections' (2013) 29(4) East European Politics 1.

${ }^{35}$ Erkan Saka, 'Tracking Digital Emergences in the Aftermath of Gezi Park Protests' (2017) 2(1) Research and Policy on Turkey 62

${ }^{36}$ Uuf Brajawidagda and Akemi Takeoka Chatfield, Roles of Social Media in Open Data Environments: A Case Study of the 2014 Indonesian Presidential Election Voting Results (ACIS 2014); Dini Suryani, 'Defending Democracy: Citizen Participation in Election Monitoring in Post-Authoritarian Indonesia' (2015) 6(1) Jurnal Studi Pemerintahan 1; Diego F Aranha, Helder Ribeiro and André Luis Ogando Paraense, 'Crowdsourced Integrity Verification Of Election Results’ (2016) Annals of Telecommunications 1; Carlos R Arias, Jorge Garcia and Alejandro Corpeño, 'Population as Auditor of an Election Process in Honduras: The Case of the VotoSocial Crowdsourcing Platform' (2015) 7(2) Policy \& Internet 185. 
And finally, a few studies consider the discussions of online publics as a possible form of crowdenabled election scrutiny. ${ }^{37}$

In sum, the surveyed studies consider a range of actors involved in contemporary domestic election monitoring, sharing characteristics with SMOs, NGOs, and interest groups. These are located on a continuum from formal organisations to networked 'crowds' of engaged citizens. The former likely have a high degree of institutionalisation, a strong and continuous membership base, and well-known repertoires of action. The latter are ad hoc, based on technological affordances, have unclear membership, and make use of intermittent and personalised repertoires of action. Therefore, the existing studies of domestic monitors can be synthesised into a useful definition of Domestic Election Monitoring Initiatives (DEMIs) ${ }^{38}$ as non-state, non-profit, non-partisan, and non-media collective actors online or offline who engage in the activity of domestic election moni-toring (as defined above).

\section{Empirical Insights}

There is considerable variation in the empirics of the surveyed studies. This is due to the varied disciplinary backgrounds of authors and journals, the research interest driving each study, and also the design and methods used. As presented in the online appendix, out of the 60 studies, more than half (34) are designed as purely qualitative descriptive case studies, most of which look at a single case (country, group, or issue), with some case comparisons and diachronic within-case comparisons. The methods employed are primarily interview-based and documentary analysis, and the majority of these studies do not explicitly put forward a dependent variable or hypothesis to test. The second largest group are experimental designs, with 12 of the surveyed studies conducting either randomised field experiments, survey experiments, or leveraging natural experiments. Seven studies combine a qualitative case study with some descriptive statistics, mainly derived from participant surveys. Only five studies use inferential statistics (i.e. various types of regression analysis), with one of them being a cross-sectional time series, and the others cross-sectional. And finally, three studies are not empirical but present formal (game theoretic) models.

Given varied research questions and goals, it is not easy to identify common themes and concise findings within the surveyed studies. But six broad areas of interest emerge, for which empirical findings are starting to be amassed. These regard (a) the prevalence of domestic monitors; (b) the drivers of participation in monitoring initiatives; (c) their 'accuracy' in detecting electoral malpractice; (d) the question of their impartiality and independence from political influences; (e) their credibility as providers of information; and (f) their impact on electoral malpractice. The findings are summarised in Table 2.

\subsection{Prevalence}

The surveyed studies give evidence that domestic monitoring has become a common component of elections in many countries around the world. Lean estimates that domestic

${ }^{37}$ Max Grömping, “"Echo Chambers”: Partisan Facebook Groups during the 2014 Thai Election’ (2014) 24(1) Asia Pacific Media Educator 39; Paul O Lazarus and Tulika A Saraf, Social Media Fostering Social Good: A Case of Election Monitoring in Nigeria (ACM 2015); Smyth and others (n 31).

38 'Initiative' is preferred to 'organisation' because it does not bias the analysis towards legacy brick-and-mortar organisations or NGOs. See also Grömping, 'Domestic Monitors’ (n 16). 
Table 2. Summary of empirical findings.

\begin{tabular}{|c|c|c|c|c|c|}
\hline Prevalence & Participation & Accuracy & Impartiality & Credibility & Impact \\
\hline $\begin{array}{l}\text { Most prevalent in } \\
\text { hybrid regimes }\end{array}$ & $\begin{array}{l}\text { Typical participants are } \\
\text { young, have high socio- } \\
\text { economic status, and } \\
\text { are very politically } \\
\text { engaged }\end{array}$ & $\begin{array}{l}\text { Domestic monitors } \\
\text { produce accurate } \\
\text { observations of } \\
\text { electoral } \\
\text { malpractice }\end{array}$ & $\begin{array}{l}\text { Impartiality is a necessary condition } \\
\text { for efficacious monitoring } \\
\text { (mixed findings) }\end{array}$ & $\begin{array}{l}\text { Domestic monitors' reports } \\
\text { affect public perceptions } \\
\text { of electoral integrity }\end{array}$ & $\begin{array}{l}\text { Presence of domestic } \\
\text { monitors increases } \\
\text { electoral integrity over } \\
\text { time }\end{array}$ \\
\hline \multirow[t]{5}{*}{$\begin{array}{l}\text { Least prevalent in } \\
\text { autocracies and } \\
\text { liberal } \\
\text { democracies }\end{array}$} & $\begin{array}{l}\text { Participation in domestic } \\
\text { monitoring builds civic } \\
\text { skills }\end{array}$ & $\begin{array}{l}\text { More accurate than } \\
\text { international } \\
\text { monitors (?) }\end{array}$ & $\begin{array}{l}\text { Perverse effects of partisan } \\
\text { monitors }\end{array}$ & $\begin{array}{l}\text { Credibility is increased by } \\
\text { impartiality and } \\
\text { professionalisation }\end{array}$ & $\begin{array}{l}\text { Domestic monitors } \\
\text { strengthen electoral } \\
\text { reform movements } \\
\text { Conducive factors: } \\
\text { - Mass perceptions of } \\
\text { electoral malpractice } \\
\text { - High party } \\
\text { institutionalisation } \\
\text { - Elite allies in political } \\
\text { parties and media }\end{array}$ \\
\hline & $\begin{array}{l}\text { Feedback loops strengthen } \\
\text { participation }\end{array}$ & & $\begin{array}{l}\text { Pro-opposition bias of domestic } \\
\text { monitors (mixed findings) }\end{array}$ & $\begin{array}{l}\text { Political influences and } \\
\text { conflicting reports by }\end{array}$ & $\begin{array}{l}\text { Domestic monitors deter } \\
\text { electoral malpractice }\end{array}$ \\
\hline & & & & $\begin{array}{l}\text { ‘zombie monitors’ } \\
\text { decrease credibility }\end{array}$ & $\begin{array}{l}\text { But: } \\
\text { - displacement of } \\
\text { malpractice to other } \\
\text { locations } \\
\text { - substitution by other types } \\
\text { of malpractice }\end{array}$ \\
\hline & $\begin{array}{l}\text { Participation in monitoring } \\
\text { may decrease or } \\
\text { increase traditional } \\
\text { electoral participation } \\
\text { (mixed findings) }\end{array}$ & & $\begin{array}{l}\text { Repression by governments, co- } \\
\text { optation by political parties, and } \\
\text { conflicting statements from } \\
\text { ‘zombie monitors' reduces } \\
\text { efficacy of domestic monitoring }\end{array}$ & $\begin{array}{l}\text { Domestic monitors less } \\
\text { credible than news media } \\
\text { (?) }\end{array}$ & $\begin{array}{l}\text { Domestic monitors may } \\
\text { socialise political elites } \\
\text { into norms of electoral } \\
\text { integrity (?) }\end{array}$ \\
\hline & & & & & $\begin{array}{l}\text { Increase of bridging social } \\
\text { capital (?) }\end{array}$ \\
\hline
\end{tabular}

Note: A question mark (?) denotes claims which are disputed or for which little to no empirical testing has been conducted to date. 
initiatives have monitored elections in 18 Latin American countries, 15 countries in South and Southeast Asia, and 17 Eastern European countries. ${ }^{39}$ And Merloe asserts that domestic election monitoring has within the last three decades '... spread to more than a hundred countries and involved millions of people'. ${ }^{40}$ Yet, there is a distinct geographical bias, insofar as the surveyed research almost exclusively covers non-OECD countries. Out of the 60 surveyed studies, not a single one dealt with domestic election monitoring in Western Europe, and only one study each covered cases in Oceania or North America (see online appendix).

This skewed geographical coverage of the research is not coincidental. It likely reflects the actual distribution of domestic monitors. Indeed, the results of a cross-sectional study of 380 monitoring groups in 111 countries show that organisational ecologies of monitors are most dense in hybrid regimes which are neither established democracies nor full autocracies, displaying an inverted U-shape pattern across levels of democratisation. ${ }^{41}$ Specifically, there are on average twice as many monitoring groups per million population in countries classified by Freedom House as 'partly free' as there are in 'not free' countries, and even three times as many when compared to 'free' countries. ${ }^{42}$ This can be explained through an interaction effect of grievances and political opportunities. In countries where elections run with high integrity, there is no need for civil society to mobilise, whereas in autocracies elections are flawed but civil society groups cannot mobilise due to repression. This likely explains the dearth of research on domestic monitoring in Western Europe, North America, and Oceania - there simply are not many research subjects to be found. Nevertheless, this pattern might change, as problems of electoral malpractice become more visible in established democracies as well.

\subsection{Participation}

Hardly any research is done about who participates in domestic monitoring, what motivates them, and what sustains participation. Although there is widespread agreement that participation in domestic election monitoring builds civic skills and social capital, very few studies gather systematic evidence. Skokova surveys 1500 election watch activists in Russia and finds that typical participants are far more politically engaged than the average citizen. For instance, 65\% had participated in demon strations in the previous year (compared to $2 \%$ among the population in general), $36 \%$ had signed a petition (3\% population average), and $30 \%$ had also participated in activities of other NGOs (2\% population average). ${ }^{43}$ There is a predominance of educated people under 45 with relatively high socioeconomic status, who are not members or supporters of parliamentary parties. Overall, participation in domestic monitoring is increased by active recruitment through NGOs, professionalisation of groups and training.

\footnotetext{
${ }^{39}$ Lean (n 13).

${ }^{40}$ Merloe (n 28) 79.

${ }^{41}$ Grömping, 'Domestic Monitors' (n 16).

${ }^{42}$ Ibid.

${ }^{43}$ Yulia Skokova, ‘НАБЛЮДАТЕЛИ НА ВЫБОРАХ В РОССИИ [Observers at the elections in Russia]' [2015] Sotsiologicheskie Issledovaniya 57.
} 
More studies look at participation in crowdsourced monitoring initiatives, perhaps because participant data is more readily accessible due to the online nature of their engagement. Arias and others survey 179 participants of the Voto Social crowdsourced quick count initiative in Honduras, and find them to be predominantly males (78\%) between 21 and 30 years of age (51\%). ${ }^{44}$ Roughly half of them said they were politically active in general, and $90 \%$ said that the platform increased their level of political activity. Hellström finds that participation in crowdmapping initiatives is strengthened through feedback loops that allow users to see what happened to their reports. ${ }^{45}$ On the other hand, he finds that engagement in online election monitoring may be a substitute for traditional participation (such as voting), which may in turn decline. Conversely, Khoo claims that the mass mobilisations of monitoring group Bersih in Malaysia have actually increased traditional electoral participation. ${ }^{46}$ Overall, the evidence is scattered and somewhat contradictory, leaving much space for future research.

\subsection{Accuracy}

Another strand of research asks whether domestic monitors - once they have come into existence - are able to detect electoral malpractices. It seems plausible that they have at least some ability in this respect, given the repertoire of scientific observation techniques they employ (e.g. parallel vote tabulation, voter list audits, sample-based observation, media monitoring). Descriptive case studies claim that monitors have successfully detected fraudulent vote counts or verified accurate ones, or presented credible evidence of inaccurate voter lists, stuffed and stolen ballot boxes, and other instances of manipulation. Due to their local nature, domestic efforts are believed to be better placed to detect malpractice than international ones, because they '.. have many more data points for analysis than do international observers, who confront the challenge of working with larger margins of error'. ${ }^{47}$

Yet, the evidence is largely anecdotal and hindered by the difficulty of establishing any benchmark measure for the 'true' extent of electoral malpractice. Very few studies tackle this issue head on. Rueda finds that domestic monitors are effective in exposing certain types of electoral malpractice that are commonly under-reported by citizens, in particular vote buying. ${ }^{48}$ Bader shows that polling places where observers report irregularities also show more election fraud as measured by two commonly used forensic indicators of fraud - turnout and vote share for an autocratic ruling party. ${ }^{49}$ Similar studies of crowdsourced quick counts find that these methods produce accurate information about the extent of malpractice or accurately verify vote tallies. ${ }^{50}$ Nevertheless, while there is some indication that domestic monitors produce accurate observation, there is still a dearth of robust and comparative evidence.

\footnotetext{
${ }^{44}$ Arias, Garcia and Corpeño (n 36).

45 Johan Hellström, ‘Crowdsourcing as a Tool for Political Participation? The Case of Ugandawatch’ (2015) 11(1) International Journal of Public Information Systems 1.

${ }^{46}$ Khoo (n 23).

${ }^{47}$ Nevitte and Canton (n 12) 60.

${ }^{48}$ Miguel R Rueda, 'Small Aggregates, Big Manipulation: Vote Buying Enforcement and Collective Monitoring’ (2017) 61(1) American Journal of Political Science 163.

${ }^{49}$ Bader (n 34).

${ }^{50}$ Aranha, Ribeiro and Paraense (n 36); Arias, Garcia and Corpeño (n 36).
} 


\subsection{Impartiality and political influences}

A key requirement of domestic election monitoring continuously emphasised in the empirical literature is its being non-partisan, neutral, and impartial. Being perceived as impartial and nonpartisan, so the reasoning goes, gives monitors legitimacy and allows them to make more impactful public statements. Some empirical evidence supports the notion that overtly partisan monitors have perverse effects on electoral malpractice. Their presence in polling places, for instance, unduly increases the vote share of the party to which these observers belong, as a study conducted in Argentina finds. ${ }^{51}$ Domestic monitors are oftentimes under suspicion of having a pro-opposition bias, not least because - especially in electoral autocracies - their recommendations are most likely to be supported by the opposition. The evidence is mixed. While Skokova's survey in Russia shows that election watch activists are neither members nor supporters of parliamentary parties, ${ }^{52}$ the survey conducted by Arias shows that half of the surveyed activists in Honduras were supporters of a smaller opposition party, which only gained $13 \%$ of the popular vote in the 2013 election. ${ }^{53}$ On the other hand, the game theoretic literature does not fully agree with the purported primacy of impartiality. The formal model developed by Chernykh and Svolik, for instance, shows that monitors do not need to be impartial to be politically consequential. ${ }^{54}$ Monitors with moderate pro-incumbent bias are acceptable to both opposition and incumbent, and in equilibrium still reduce the overall amount of electoral malpractice.

In any case, possible partisan biases are believed to be especially consequential in divided societies or in autocracies where a dominant party has a strong grip on power. Lean provides one of the few comparative accounts in this regard, showing that in Venezuela, domestic monitors are mostly seen as partisan proxies because of the extremely polarised political environment of the country, whereas in Mexico, a less polarised society, monitors have been able to assert their independence and neutrality. ${ }^{55}$

Impartiality may also be undermined through the exercise of political influence over domestic monitors. Harassment and extended incarceration of election watch activists in Azerbaijan or Bangladesh, draconian anti-NGO laws in Ethiopia, and ever-shrinking public space for electoral reform advocacy in Cambodia are discussed in one article. ${ }^{56}$ And a longitudinal qualitative case study by Makulilo in Tanzania shows how a monitoring NGO becomes slowly co-opted by the state and over the course of three electoral cycles issues more and more acquiescent statements about the integrity of the elections. ${ }^{57}$ Even more serious may be the interference of so-called 'zombie' or 'shadow' monitors, international groups invited as a strategy of authoritarian legitimation to certify fraudulent

\footnotetext{
${ }^{51}$ Agustín Casas, Guillermo Diaz and André Trindade, 'Who Monitors the Monitor? Effect of Party Observers on Electoral Outcomes’ (2017) 145 Journal of Public Economics 136.

52 Skokova (n 43).

${ }^{53}$ Arias, Garcia and Corpeño (n 36).

${ }^{54}$ Svitlana Chernykh and Milan W Svolik, 'Third-Party Actors and the Success of Democracy: How Electoral Commissions, Courts, and Observers Shape Incentives for Electoral Manipulation and Post-Election Protests’ (2015)

77(2) The Journal of Politics 407.

${ }^{55}$ Lean (n 13).

${ }^{56}$ Merloe (n 28).

57 Alexander Boniface Makulilo, "'Watching the Watcher”: An Evaluation of Local Election Observers in Tanzania' (2011) 49(2) The Journal of Modern African Studies 241.
} 
elections or to at least cast enough doubt on the reports of Western-sponsored observers that public confusion ensues. ${ }^{58}$

\subsection{Credibility}

Is the information about electoral malpractice provided by domestic monitors believable to the targeted audiences - be they the general public, news media, electoral authorities or international organisations? In one study specifically related to international election monitoring groups, increases in credibility are associated with professionalisation, governance structures that demonstrate independence, as well as transparent funding and intraorganisational processes. ${ }^{59}$ However, comparable evidence for domestic monitors is scattered. Botero and collaborators show that information provided by domestic monitors about the corruption of political candidates is less credible to voters than the same information provided by newspapers. ${ }^{60}$ Bush and Prather find that the origin of a monitoring group (foreign or domestic) does not influence its credibility as perceived by the general public, nor its ability to influence perceptions of electoral integrity. ${ }^{61}$ Descriptive case studies suggest that certain factors, such as the endorsement of international standards of monitoring and codes of conduct signals credibility of domestic monitors, ${ }^{62}$ whereas lack of professionalism, political ties, and dependency on donor conditionalities, undermine it. ${ }^{63}$ Conflicting election reports by GONGOs ('zombie monitors') may also negatively affect credibility. ${ }^{64}$ But is unclear how robust this evidence is in a comparative perspective.

Overall, some indications exist that monitors' reports do affect public perceptions, that accuracy and impartiality are antecedents of credibility, and that certain factors related to professionalisation may also enhance it. But these propositions are open for testing, and much research remains to be done about the credibility of domestic monitors.

\subsection{Impacts on electoral integrity}

Finally, the million-dollar question occupying much of the literature is of course whether domestic monitors measurably strengthen electoral integrity. However, at the time of writing, there is only one globally comparative study in this regard. It draws on an impressive crossnational time-series dataset of more than 1000 elections between 1990 and 2012 to convincingly demonstrate that the presence of domestic monitors increases electoral integrity over time, especially when the autonomy of electoral management bodies is low (substitution effect). ${ }^{65}$ Beyond this benchmark study, researchers have

\footnotetext{
${ }^{58}$ Maria Debre and Lee Morgenbesser, 'Out of the Shadows: Autocratic Regimes, Election Observation and Legitimation’ (2017) 23(3) Contemporary Politics 328.

${ }^{59}$ Susan D Hyde, 'Why Believe International Election Monitors?' in Peter Alexis Gourevitch, David A Lake and Janice Gross Stein (eds), The Credibility of Transnational NGOs When Virtue Is Not Enough (Cambridge University Press 2012).

${ }^{60}$ Sandra Botero and others, 'Says Who? An Experiment on Allegations of Corruption and Credibility of Sources' (2015) 68(3), Political Research Quarterly 493.

${ }^{61}$ Sarah Sunn Bush and Lauren Prather, 'The Promise and Limits of Election Observers in Building Election Credibility' (2017) 79(3) The Journal of Politics 921.

${ }^{62}$ Merloe (n 28).

${ }^{63}$ Makulilo (n 57).

${ }^{64}$ Debre and Morgenbesser (n 58).

${ }^{65}$ Birch and Van Ham (n 15).
} 
struggled with the question of impact because of the very fact that the presence of watchdogs is systematically skewed towards those countries in which elections are marred by malpractice (see above). This selection bias impedes cross-national investigations. Scholars have tackled this issue by focusing on effects of observers at the micro-level, where randomisation or quasi-experiments are feasible, or by investigating intermediate causal mechanisms. A related challenge is that the surveyed studies do not agree about what impacts domestic election monitors could potentially have. In other words, a range of different dependent variables are developed in the literature. Not only do different studies focus on different outcomes, they also propose differing causal mechanisms: (a) some studies focus upon policy advocacy and electoral reform; (b) others draw on constructivist theories leading to ideational or norm-building effects of monitors; (c) other studies rely on rational choice arguments to explain deterrence of election fraud; (d) yet others emphasise social capital; and (e) some remain entirely agnostic about how exactly monitors could make a difference. As a result, not only are the theoretical models disjointed from one another, the causal mechanisms by which elections are believed to be strengthened are also undertheorised. In an attempt to summarise the debate, this section considers only the most robust findings.

First, a number of studies investigate whether and under which circumstances domestic election monitoring and advocacy groups create public pressures for electoral reform. By directly appealing to politicians' normative ideals of electoral integrity, or by imposing legitimacy costs on them through media campaigns and public actions, monitors become-advocates can nudge the reform process towards legislation conducive for clean elections, as has happened, for instance, in the expansion of gender quota laws. ${ }^{66}$ They may be aided in this endeavour by mass perceptions of widespread malpractices creating further public pressure. ${ }^{67}$ Other conducive factors for electoral reform advocacy by domestic monitors may be high party institutionalisation and low degrees of co-optation, which increase political parties' constructive engagement with electoral reform movements. ${ }^{68}$ Furthermore, the aforementioned case study of electoral reform in New Zealand suggests that advocacy groups promoting electoral reform are more likely to be successful if there are media allies, party system dealignment, and a political culture supporting populist democratic values. ${ }^{69}$

In a second approach, some studies draw on constructivist arguments from social movement scholarship and international relations and hold that an important impact of domestic monitors would come from socialising political elites into international norms of electoral integrity. Through consciousness-raising, shaming, argumentation and persuasion they may be successful in promoting integrity norms until they achieve 'prescriptive status', meaning that elites adhere to them out of habit. The success of domestic monitors in establishing regional norms of electoral integrity is empirically documented in Lean's comparative case study of Latin America. ${ }^{70}$ However, due to the discursive nature of this causal mechanism, measurable quantitative evidence is difficult to establish. The same is true for similar studies of the effect of domestic monitors on social capital. For

\footnotetext{
${ }^{66}$ Celis, Krook and Meier (n 26).

${ }^{67}$ Pippa Norris, ‘Cultural Explanations of Electoral Reform: A Policy Cycle Model’ (2011) 34(3) West European Politics 531.

68 Semenov, Lobanova and Zavadskaya (n 24).

${ }^{69}$ Vowles (n 25).

${ }^{70}$ Lean (n 13).
} 
instance, Trujillo and others argue, in their case study of Kenya, that crowdmapping of electoral malpractices increases inter-ethnic bridging social capital. ${ }^{71}$ This in turn can help mitigate election violence. Other claims in the same vein are made by Nevitte and Canton. ${ }^{72}$ But again, empirical evidence is mostly anecdotal and non-comparative.

Third, the most robust evidence about impacts thus far has been generated by studies drawing on rational choice theory. The game theoretic models informing these studies argue that domestic election monitors act as an informational device - providing a publicly observable signal about the quality of an election. This information solves the coordination problem of the public and allows it to pose a credible threat of protest or rebellion against political candidates - especially incumbents - who try to manipulate elections. This increases incentives for incumbents to provide demonstrably fair elections and in turn is believed to deter electoral malpractice from occurring. ${ }^{73}$ An important intermediate step in this causal argument is investigated by Bush and Prather, who show that negative statements by domestic monitors about the integrity of an election decrease voters' perceptions of electoral integrity. ${ }^{74}$ And at least for international observers, negative reports have been associated with a higher propensity for post-election protest, thereby imposing costs on cheating politicians. ${ }^{75}$ While a similar test for domestic monitors is still pending, research has been able to verify the hypothesised deterrence effect at the micro-level. A number of randomised field experiments have amassed convincing evidence that the presence of domestic monitors in polling places reduces the occurrence of pre-electoral or election-day manipulations. ${ }^{76}$ Impacts of photo quick counts ${ }^{77}$ and anti-violence campaigns ${ }^{78}$ by domestic monitors have also been demonstrated via similar experiments. Still, the same studies also show that manipulations are often merely displaced geographically or substituted by other types of malpractice, and it must be noted that one experimental study found little to no effect of the presence of monitors on fraud. ${ }^{79}$

\footnotetext{
${ }^{71}$ Horacio R Trujillo and others, 'The Role of Information and Communication Technology in Preventing ElectionRelated Violence in Kenya, 2013’ (2014) 13(1-2) Perspectives on Global Development and Technology 111.

${ }^{72}$ Nevitte and Canton (n 12).

73 James D Fearon, ‘Self-Enforcing Democracy’ (2011) 126(4) Quarterly Journal of Economics 1661; Andrew T Little, 'Elections, Fraud, and Election Monitoring in the Shadow of Revolution' (2012) 7(3) Quarterly Journal of Political Science 249; Chernykh and Svolik (n 54).

${ }^{74}$ Bush and Prather (n 61).

${ }^{75}$ Hyde and Marinov (n 7).

${ }^{76}$ Joseph Asunka and others, 'Electoral Fraud or Violence: The Effect of Observers on Party Manipulation Strategies' (2017) British Journal of Political Science 1, doi:10.1017/S0007123416000491; Ruben Enikolopov and others, 'Field Experiment Estimate of Electoral Fraud in Russian Parliamentary Elections’ (2013) 110(2) Proceedings of the National Academy of Sciences 448; Nahomi Ichino and Matthias Schündeln, 'Deterring or Displacing Electoral Irregularities? Spillover Effects of Observers in a Randomized Field Experiment in Ghana' (2012) 74(1) The Journal of Politics 292; Stefanus Leeffers and Pedro C Vicente, Does Electoral Observation Influence Electoral Results? Experimental Evidence for Domestic and International Observers in Mozambique (2017); Fredrik M Sjoberg, 'Making Voters Count: Evidence From Field Experiments about the Efficacy of Domestic Election Observation’ (2012) October 2012 Columbia University Harriman Institute Working Paper.

${ }^{77}$ Michael Callen and James D Long, 'Institutional Corruption and Election Fraud: Evidence from a Field Experiment in Afghanistan' (2015) 105(1) The American Economic Review 354; Michael Callen and others, 'Improving Electoral Integrity with Information and Communications Technology’ (2016) 3(1) Journal of Experimental Political Science 4.

${ }^{78}$ Paul Collier and Pedro C Vicente, 'Votes and Violence: Evidence from a Field Experiment in Nigeria' (2014) 124(574) Economic Journal F327.

${ }^{79}$ Andrei Buzin, Kevin Brondum and Graeme Robertson, 'Election Observer Effects: A Field Experiment in the Russian Duma Election of 2011’ (2016) 44 Electoral Studies 184.
} 


\section{Conclusion}

Domestic election monitoring is still a relatively young phenomenon. In the 1980s, when pioneering organisations such as the Filipino group NAMFREL first started their observation and advocacy efforts, nobody would have expected that in the decades to follow, similar groups would begin to operate in more than a hundred countries around the world. This is a testament to the resilience and conviction of election watch activists. This review article set out to draw together the scattered body of scholarly research on domestic election monitoring from different disciplines. It tried to provide a rough map of the emerging research agenda on domestic monitors by summarising definitions and empirical insights.

There are several important takeaway points. On the one hand, despite the disparate and scattered nature of the existing body of literature in terms of epistemology, research questions, research design, methods, and geographical scope, there are some major areas of agreement. Namely, a recognition that election monitoring goes beyond election-day pollwatching, but rather encompasses a large spectrum of activities around the whole electoral cycle, including long-term advocacy. In addition, while there may be disagreement over what organisational form domestic monitoring takes, studies converge on some core characteristics, such as them being nonpartisan, non-state, non-media, and non-profit. Furthermore, studies agree that domestic monitors are by and large able to produce accurate information about electoral malpractice, and that their efficacy is aided by staunch impartiality and independence from political influences, and professionalism.

On the other hand, the majority of existing studies are not suited to drawing broader crossnational generalisations across diverse elections, contexts and types of regimes: both descriptive case studies and experiments have limited generalisability. This extends to the findings regarding credibility, participation, and in particular impacts. While there is for example convincing and robust evidence for the deterrence effect of domestic monitors, it is unclear to what extent these findings 'travel' to other contexts. The only existing cross-section time-series analysis ${ }^{80}$ suggests that they might, but why and under which conditions is less clear. In addition, some evidence about impacts on electoral reform is starting to accumulate, but much less is known about the longer-term impacts on norm building or social capital. Clearly, more evidence, especially more comparative evidence, is needed to make any broader assertions about if and under which conditions domestic monitors improve elections.

Finally, the emerging research agenda on domestic monitors provides fertile ground for future investigations. Perhaps most importantly, the theoretical framework and causal mechanisms discussed need consolidation. Currently, studies investigating deterrence, electoral reform, or norm building, for instance, have few points of contact. The empirical evidence is correspondingly disjointed and does not take interdisciplinary findings into account. An approach that might be useful in this regard is a focus on the communicative processes by which information and frames generated by domestic election monitors reach different audiences. Each of the three dominant theoretical approaches - rational choice/deterrence; public policy/electoral reform; and constructivism/norm-building -

${ }^{80}$ Birch and Van Ham (n 15). 
are agnostic about how and under which circumstances monitors' information and frames proliferate to audiences. This certainly needs unpacking.

Other promising questions for future research include those related to organisational characteristics of domestic monitoring groups, both at the group level and at the ecological level. We need to know more about their organisational morphologies, funding, staffing, observation methods, advocacy strategies, and engagement with other national and international actors. Who joins them and why; and how have communication technologies changed participation? Furthermore, questions about the source credibility of domestic election monitors await answering. Do negative reports about election quality affect perceptions of malpractice, either of the public or of political elites? Future research should also delve further into the possible political agenda-setting effects of domestic monitors. Under what conditions does media coverage of these groups and/or their election observation reports increase the salience of electoral integrity on the political agenda? And finally, how does the advent of crowdsourced election monitoring alter participation in monitoring groups and the impacts they can expect to achieve?

All of these questions make for an exciting future research agenda on the causes and consequences of domestic election monitoring.

\section{Acknowledgement}

This work was supported by a PhD scholarship provided under the Australian Research Council Kathleen Fitzpatrick Australian Laureate Fellowship Award [FL110100093].

\section{ORCID}

Max Grömping http://orcid.org/0000-0003-1488-4436 